\title{
POMIAR INWENTARYZACYJNY OBIEKTÓW PRZEMYSŁOWYCH PRZY UŻYCIU NAZIEMENGO SKANINGU LASEROWEGO W ASPEKCIE WDRAŻANIA TECHNOLOGII BIM
}

\author{
Łukasz Uchański ${ }^{1}, K^{\prime}$ rzysztof Karsznia ${ }^{2}$ \\ Czerski Trade Polska Sp. z o.o., Warszawa \\ ${ }^{2}$ Wydział Budownictwa i Inżynierii Środowiska, Szkoła Główna Gospodarstwa Wiejskiego w Warszawie, Warszawa
}

\begin{abstract}
STRESZCZENIE
Geodezyjne pomiary inwentaryzacyjne obiektów przemysłowych stanowią niezbędny element ich utrzymania. Przykładem takiego obiektu jest choćby chłodnia kominowa, dla której autorzy niniejszego artykułu dokonali analizy możliwości wykorzystania naziemnego skaningu laserowego w pomiarach inwentaryzacyjnych. Podstawowym problemem badawczym, który stanowił motywację do podjęcia realizacji zadania, była weryfikacja możliwości wykorzystania technologii skanowania laserowego jako uzupełnienia lub nawet jako substytutu dotychczas stosowanych geodezyjnych metod pomiarowych. Kolejnym aspektem jest kwestia pozyskania danych pozwalających na weryfikację przydatności opracowania modelu obiektu w technologii BIM (ang. building information modeling/management) poprzez odtworzenie jego konstrukcji wraz z pełną informacją projektową w interaktywnym środowisku 3D. Technologia BIM umożliwia bowiem zarówno prowadzenie szeroko zakrojonych analiz konstrukcyjnych czy wytrzymałościowych, sprawne zarządzanie obiektem wraz z jego parametrami, jak i optymalne planowanie potencjalnych remontów.
\end{abstract}

Słowa kluczowe: naziemny skaning laserowy (TLS), BIM, pomiar inwentaryzacyjny, chłodnia kominowa, chmura punktów, model 3D

\section{WSTĘP}

Geodezyjna obsługa inwestycji przebiega na bazie aktów prawnych, norm, przepisów i instrukcji branżowych. Warunkują ją także procedury odzwierciedlające stan wiedzy oraz postęp technologiczny (Gocał, 1999; Szulborski 1999; Pawłowski, 2015). Współdziałanie geodetów ze specjalistami pokrewnych dziedzin - budownictwa, inżynierii sanitarnej itp. - ma miejsce podczas całego przebiegu procesu inwestycyjnego. Co więcej przepisy branżowe wymagają prowadzenia przez geodetów inwentaryzacji powykonawczej, a także okresowej kontroli stanu geometrii ocenianego obiektu. Ostatnimi czasy coraz większego znaczenia nabiera monitoring stanu konstrukcji - SHM (ang. structural health monitoring), co jest spowodowane dynamicznym rozwojem technologii instrumentalnej oraz geoinformacyjnej. Obiekty o dużej istotności, pełniące ważną rolę w zapewnieniu bezpieczeństwa ludzi i mienia oraz stanowiące ważny element infrastruktury podlegają często monitoringowi ciągłe$\mathrm{mu}$, dostarczającemu bieżących informacji na temat zachodzących zmian geometrycznych oraz cech fizycznych konstrukcji. Rozwój technologii przetwarzania i archiwizowania danych o obiektach bezpośrednio wpływa na 
konieczność doboru nowych metod akwizycji danych. Urządzenia pomiarowe dostarczające dużych zbiorów danych geometrycznych uzupełnionych innymi informacjami, jak choćby odnośnie struktury badanego materiału, znalazły swoje stałe miejsce w pracach geodezyjnych. Efektywność metod zdalnych - fotogrametrycznych i teledetekcyjnych - sprawia, iż coraz częściej mogą być stosowane, jako substytut znanych, klasycznych metod pomiarowych bądź też jako ich niezbędne uzupełnienie.

Szczególnego znaczenia nabiera opracowanie optymalnej strategii kontroli i oceny stanu konstrukcji przemysłowych. Istotnym elementem infrastruktury przemysłowej są zatem drogi, wiadukty, mosty czy choćby budowle wieżowe - maszty, kominy, oraz chłodnie. Biorąc zatem pod uwagę złożoność procesu inwentaryzacji wymienionych obiektów, stajemy przed zagadnieniem odpowiedniego doboru narzędzi niezbędnych do realizacji tego zadania. Pojawia się w związku z tym pytanie, czy poprzestać należy jedynie na samym pomiarze weryfikacyjnym geometrii obiektu (pomiar kontrolny), czy też należy dodatkowo pozyskiwać dane, które można wykorzystać w przyszłości. Jeśli odpowiedź będzie związana jedynie z aspektem czysto weryfikacyjnym (kontrola geometrii konstrukcji), wyboru będziemy dokonywać między klasycznymi pomiarami geodezyjnymi realizowanymi z użyciem tachimetrów elektronicznych a niwelacją precyzyjną oraz naziemnym skaningiem laserowym (TLS - ang. terrestrial laser scanning) reprezentującym grupę technologii fotogrametrycznych. Jeżeli jednak będziemy skłaniać się ku opracowaniu bardziej złożonemu, wówczas powinniśmy zdecydowanie rozważyć użycie samego skaningu laserowego. Od niedawna dużą popularnością cieszy się technologia BIM dotycząca modelowania informacji o budynkach bądź zarządzania taką informacją (z ang. building information modeling/management), stając się powoli standardem $\mathrm{w}$ aspekcie prowadzenia inwestycji budowlanych w Polsce. Technologia BIM obejmuje całość tego procesu - począwszy od fazy projektowej, przez wykonawczą, aż po eksploatację obiektów. Wirtualne środowisko, w którym mamy do czynienia z projektem ,żyjącym” w czasie jego realizacji, z uwzględnieniem orientacji przestrzennej, uzupełnionego o zestaw informacji/atrybutów, dostarcza projektantom, inżynierom, wykonawcom oraz administratorom danego obiektu budowlanego wiele istotnych korzyści (Tomana, 2016). W kontekście BIM priorytetowego znaczenia nabiera technologia pozyskiwania danych przestrzennych, jaką jest naziemny skaning laserowy (TLS) - pozwalający na szybką akwizycję dużych ilości danych 3D. Dodać należy, iż w wielu przypadkach pierwotna dokumentacja projektowa obiektów budowlanych występuje jedynie w formie analogowej, bywa zdekompletowana lub po prostu korzystanie $\mathrm{z}$ niej jest $\mathrm{z}$ różnych przyczyn utrudnione. Technologia BIM bazuje na zasadzie współdzielenia informacji między uczestnikami zaangażowanymi w realizację projektu, dlatego znajduje uzasadnienie również w kontekście tzw. inżynierii odwrotnej, $\mathrm{z}$ ang. reverse engineering (Uchański i Soerensen, 2010). Inżynieria odwrotna pozwala bowiem na odtworzenie pierwotnej dokumentacji projektowej za pomocą inwentaryzacji stanu zastanego oraz przeniesienie jej do formy 3D, która po uzupełnieniu o informacje dodatkowe (atrybuty obiektów) stanowi pełnowartościowy system geoinformacyjny.

\section{ZAŁOŻENIA BADAWCZE}

Możliwość zastosowania technologii skaningu laserowego do uzupełnienia modelu BIM zakładu przemysłowego autorzy przetestowali w odniesieniu do chłodni kominowej. Zastosowanie metody TLS pozwoliło na otrzymanie w krótkim czasie obszernego zbioru informacji odzwierciedlającego faktyczną geometrię obiektu (rys. 1).

Przeprowadzone badania miały także posłużyć do określenia, w jakim stopniu technologia naziemnego skaningu laserowego może być alternatywą dla klasycznych pomiarów geodezyjnych wykorzystywanych do oceny oraz monitoringu geometrii konstrukcji obiektów inżynierskich. Dokonano również oceny możliwości połączenia technologii TLS z klasycznymi metodami geodezyjnymi w celu usprawnienia tzw. orientacji i rejestracji chmur punktów 3D. 
Rys. 1. Widok chmury punktów zarejestrowanej podczas skanowania chłodni kominowej zwizualizowanej w tonacji ,odbiciowej” (opracowanie własne)

Fig. 1. View of the point cloud registered during cooling tower laser scanning visualized as "reflectance" (own elaboration)

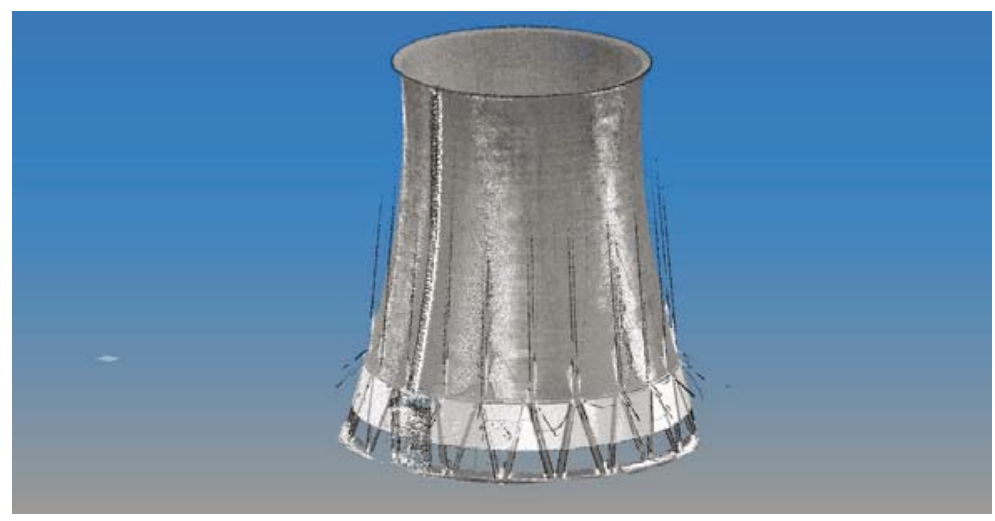

\section{OPIS OBIEKTU I ZAKRES WYKONANYCH PRAC}

Wybór obiektu został podyktowany charakterystyką konstrukcji przemysłowej samego budynku stawiającej przed prowadzącymi prace pomiarowe wiele wyzwań (Głowacki, Grzempowski, Sudoł, Wajs i Zając, 2016; rys. 2).

Przed rozpoczęciem prac rozważano wykorzystanie różnorodnych technologii pomiarowych, od klasycznych metod geodezyjnych (pomiar sieci kątowo-liniowej), poprzez skaning fazowy oraz impulsowy (Uchański, Falkowski i Uchański, 2010). Zdecydowano się na wykorzystanie skaningu impulsowego ze względu na kompleksowość pozyskiwanej informacji, jej dokładność oraz szybkość pracy urządzenia (Zaczek-Peplinska i Popielski, 2013).

Skaner laserowy wyposażony jest w głowicę skanującą, która emituje wiązkę laserową padającą na otaczające powierzchnie. Zakres pracy urządzenia można dowolnie modyfikować - może wynosić on nawet $360^{\circ} \mathrm{w}$ płaszczyźnie poziomej (dostarczając do opracowania chmurę punktów reprezentującą całą dostępną przestrzeń) oraz $90^{\circ} \mathrm{w}$ płaszczyźnie pionowej (tab. 1). Prędkość obrotowa głowicy skanującej zapewnia rozdzielczość pomiaru nawet na poziomie miliona punktów na sekundę (w omawianym przypadku było to ok. 40 tys. punktów na sekundę). Zależy to głównie od rodzaju skanera (urządzenia impulsowe lub fazowe). Zasadą działania instrumentów impulsowych jest precyzyjny pomiar czasu między emisją a powrotem do układu odczytowego wyemitowanego impulsu wiązki laserowej. W skanerach fazowych ocenie poddawana jest faza fali nośnej. Wykonywany w ten sposób, znany w geodezji pomiar biegunowy polegający na określeniu odległości między stanowiskiem a punktem pomiarowym oraz wartości kierunku uzupełniany jest dodatkowo o dane na temat odbicia wiązki od powierzchni tzw. intensity image (Zaczek-Peplinska i Popielski, 2013;

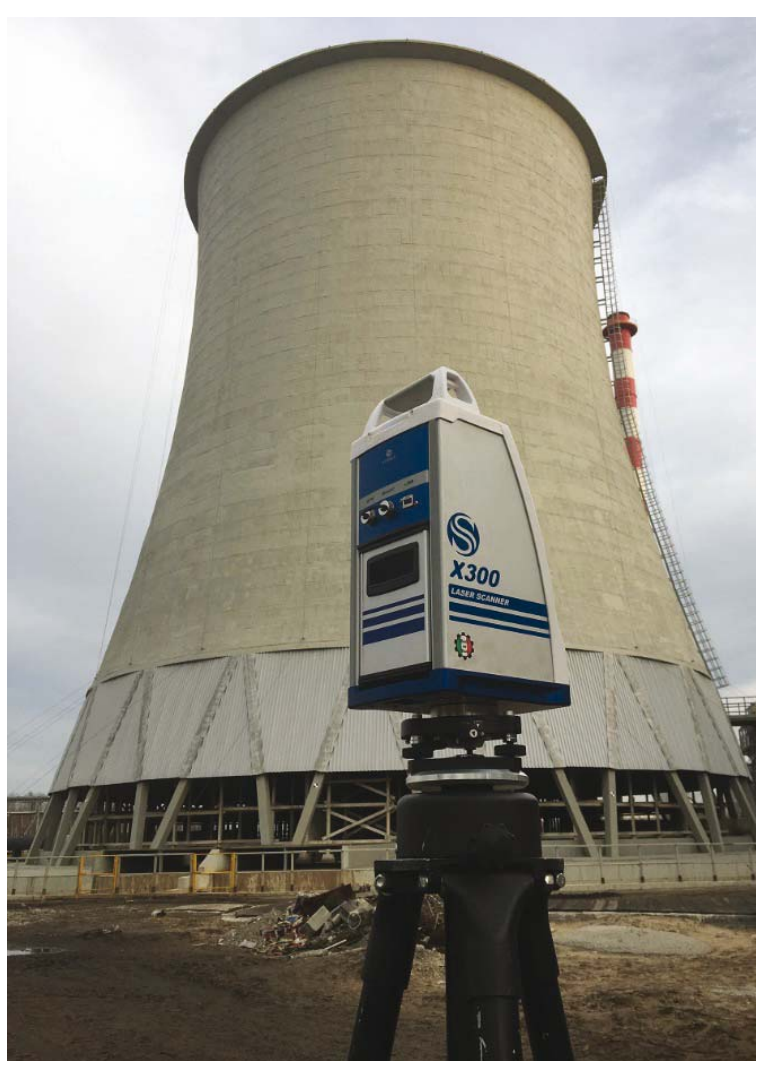

Rys. 2. Widok chłodni kominowej w trakcie skanowania (fot. K. Karsznia)

Fig. 2. View of the cooling tower during laser scanning (photo by K. Karsznia) 
Uchański, Ł., Karsznia, K. (2017). Pomiar inwentaryzacyjny obiektów przemysłowych przy użyciu naziemengo skaningu laserowego w aspekcie wdrażania technologii BIM. Acta Sci. Pol. Architectura, 16 (4), 71-82. doi: 10.22630/ASPA.2017.16.4.07.

Karsznia, 2014). Dobór odpowiedniej technologii zależy zatem od wymaganego czasu realizacji pomiaru, zasięgu oraz oczekiwanej dokładności (Uchański, Falkowski i Uchański, 2010).

Dla potrzeb realizacji niniejszego projektu wybrano impulsowy skaner laserowy 3D Stonex X300 (rys. 3). Instrument ten ze względu na swoje parametry jest odpowiednio przystosowany do specyfiki i uwarunkowań realizacji zadania. Wybrany instrument jest urządzeniem średniego zasięgu, idealnie przystosowanym do wykorzystania w obiektach przemysłowych, mieszkalnych, kubaturowych oraz w pomiarach topograficznych.

W tabeli 1 przedstawiono podstawowe parametry techniczne wykorzystanego urządzenia.

Komputerowe opracowanie danych pozyskanych przy wykorzystaniu skanera laserowego przeprowadzono za pomocą oprogramowania JRC 3D Reconstructor w najnowszej aktualnie wersji 3.3.0.

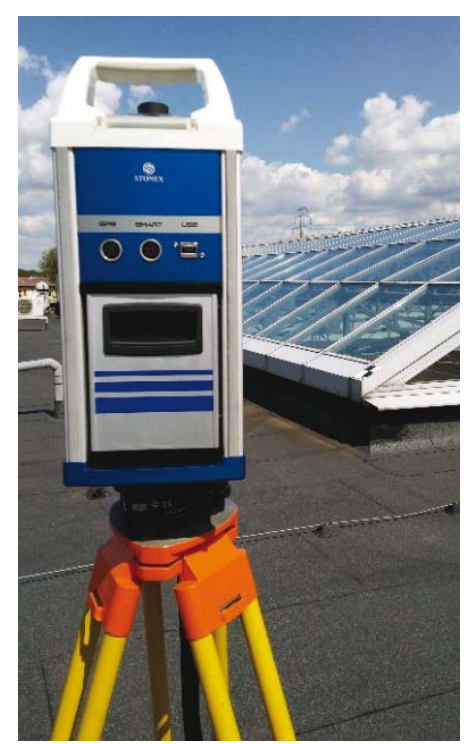

Rys. 3. Widok skanera laserowego Stonex X300 (fot. K. Karsznia)

Fig. 3. View of the laser scanner Stonex X300 (photo by K. Karsznia)
Tabela 1. Parametry techniczne skanera Stonex X300 (firma Stonex)

Table 1. Technical parameters of Stonex X300 laser scanner (Stonex)

\begin{tabular}{lc}
\hline & \multicolumn{1}{c}{ Cecha } \\
\hline & Wydajność \\
\hline Zasięg & $\begin{array}{l}1,6-300 \mathrm{~m} \text {, przy } 100 \% \text { albedo } \\
\text { (dla bieli) }\end{array}$ \\
\hline
\end{tabular}

\begin{tabular}{ll}
\hline Zakres rejestracji skanera & \\
\hline W płaszczyźnie poziomej & $360^{\circ}(\mathrm{w}$ pełni panoramiczny $)$ \\
\hline W płaszczyźnie pionowej & $90^{\circ}\left(-25^{\circ}\right.$ do $\left.+65^{\circ}\right)$ \\
\hline Prędkość skanowania & do 40000 punktów na sekundę \\
\hline Wielkość siatki & $39 \mathrm{~mm} \times 39 \mathrm{~mm}$ na $100 \mathrm{~m}$ \\
\hline Wielkość plamki lasera & $0,37 \mathrm{mrad}$ \\
\hline Rozdzielczość kątowa & $\begin{array}{l}1,35^{\prime}(\mathrm{H}) \times 1,35^{\prime}(\mathrm{V})(\text { przy } \\
\text { maksymalnej rozdzielczości })\end{array}$ \\
\hline Dokładność pomiaru odległości & $\begin{array}{l}<6 \mathrm{~mm} \text { na } 50 \mathrm{~m}(1) \\
<40 \mathrm{~mm} \text { na } 300 \mathrm{~m}\end{array}$
\end{tabular}

\begin{tabular}{ll}
\hline & System \\
\hline Optyka skanera & $\begin{array}{l}\text { pionowo obracające się lustro, } \\
\text { poziomo obracąaca się baza }\end{array}$ \\
\hline Klasa lasera & Klasa 1M 9IEC 60825-1 \\
\hline Długość wiązki lasera & 905 nm (niewidoczny) \\
\hline Dwuosiowy kompensator & dokładność $0,08^{\circ}$, zakres $+/-20^{\circ}$ \\
\hline Zintegrowane kamery & 5 Mpx \\
\hline Rozdzielczość & $1943 \times 2592 \times 2$ px \\
\hline Przechowywanie danych & zintegrowana pamięć 32 Gb \\
\hline Transfer danych & Wi-Fi, urządzenie USB, Ethernet \\
\hline Sterowanie skanerem & przez dedykowany interfejs Web \\
\hline Wi-Fi dla smartfona/tabletu (Android, \\
\hline Zasilanie & Zasilanie \\
\hline Zużycie energii & $12 \mathrm{~V}$ (bateria lub zewnętrzne źródło \\
\hline Rodzaj baterii & $40 \mathrm{~W}$ (zazwyczaj) \\
\hline Czas pracy na baterii & Li-Poly \\
\hline Waga i rozmiary skanera & $>3 \mathrm{~h}$ \\
\hline Waga i rozmiary baterii & $6,15 \mathrm{~kg}, 215 \times 170 \times 430 \mathrm{~mm}$ \\
\hline Waga i rozmiary ładowarki & $200 \mathrm{~g}, 147 \times 63 \times 38 \mathrm{~mm}$ \\
\hline Temperatura pracy & od -10 do $+50^{\circ} \mathrm{C}$ \\
\hline Odporność na pył i wodę & od -25 do $+80^{\circ} \mathrm{C}$ \\
\hline Wilgotność & bez kondensacji \\
\hline
\end{tabular}


Oprogramowanie to posłużyło do wstępnej rejestracji danych, w szczególności konwersji ich formatu wyjściowego do zgodnego ze środowiskiem operacyjnym oprogramowania. W dalszej kolejności, dokonano za jego pomocą połączenia chmur punktów ze wszystkich stanowisk skanera w jeden wspólny i wyrównany metodą najmniejszych kwadratów układ współrzędnych. Dokładność takiego opracowania wyniosła $\pm 5 \mathrm{~mm}$.

W związku z tym, iż pomiar obiektu przeprowadzono z uwzględnieniem lokalnego układu współrzędnych zakładu przemysłowego, zaistniała konieczność dowiązywania zarejestrowanych chmur punktów do istniejącej osnowy realizacyjnej. Do tego celu użyto specjalnych tarcz celowniczych (rys. 4), których współrzędne środków zostały pomierzone przy wykorzystaniu tachimetru elektronicznego Leica TCR803, charakteryzującego się dokładnością pomiaru kąta na poziomie \pm 3 " oraz odległości $\pm 2 \mathrm{~mm}+2 \mathrm{~mm} \cdot \mathrm{km}^{-1}$ (Leica Geosystems, 2006). Tarcze celownicze (20 szt.) zostały rozlokowane równomiernie na dolnych elementach konstrukcyjnych chłodni, na różnych wysokościach, co miało na celu zminimalizowanie wpływu propagacji błędu orientacji całego układu. Ponadto wokół każdego stanowiska skanera zostały zainstalowane tarcze dodatkowe w taki sposób, aby uwzględniając ich współdzielenie na kilku stanowiskach skanowania, zawsze było „widocznych” przynajmniej pięć (taka liczba punktów odniesienia umożliwia wykonanie optymalnej ,georeferencji” wraz z pełną analizą dokładności).

Następnie dokonano filtracji zarejestrowanych danych w programie JRC 3D Reconstructor ${ }^{\circledR}$, pozbywając się wszelkich szumów oraz artefaktów powstałych podczas prac pomiarowych.

Przygotowane w ten sposób materiały wyjściowe stanowią cenne źródło danych dla potrzeb opracowania kompleksowej dokumentacji 3D. Do tego celu wykorzystać można przykładowo oprogramowanie Autodesk Design Building Suite. Do wymiany danych między wspomnianymi platformami posłużył format e57, który zapewnia bezstratną wymianę informacji. Tym samym jesteśmy w stanie rozpocząć budowę kompleksowego modelu BIM badanego obiektu, stopniowo uzupełnić go o coraz szerszą tkankę informacyjną, począwszy od wartości geometrycznych, poprzez wprowadzanie wszystkich istotnych parametrów fizycznych, „ożywiając” całość obiektu w trójwymiarowym środowisku (Hardin i McCool, 2015).

\section{REZULTATY PRAC POMIAROWYCH}

Przeprowadzone prace z wykorzystaniem skanera miały za zadanie posłużyć autorom do analizy możliwości wykorzystania ich zarówno dla potrzeb przyszłego łączenia klasycznych geodezyjnych oraz fotogrametrycznych metod pomiarowych, jak i uzupełnienia ich o dane dodatkowe, dopełniające informacje w modelu BIM danego obiektu. Ich wykonanie pomogło także zweryfikować możliwość prowadzenia cyklicznych pomiarów inwentaryzacyjnych jedynie z wykorzystaniem fotogrametrii bliskiego zasięgu.

Biorąc pod uwagę zalety oraz ograniczenia zastosowania metody TLS, można stwierdzić, iż od dokładności i rzetelności wykonanych prac terenowych zależy bezpośrednio jakość zbudowanego na dalszym etapie modelu 3D w technologii BIM. Prawidłowe dobranie systemu skanującego pod względem jego rodzaju oraz rozplanowanie stanowisk skanera (pozwalających na rejestrację jak największej ilości danych przy ekonomicznym uzasadnieniu czasu poświęconego na akwizycję) mają bezpośredni wpływ na koszt wykonywanego opracowania, jak również jego użyteczność produkcyjną. Zaleca się zatem, aby każdorazowo projekt akwizycji danych w terenie był przygotowany oraz zweryfikowany in situ, bezpośrednio przed rozpoczęciem prowadzenia rzeczonych prac pomiarowych (rys. 5). 


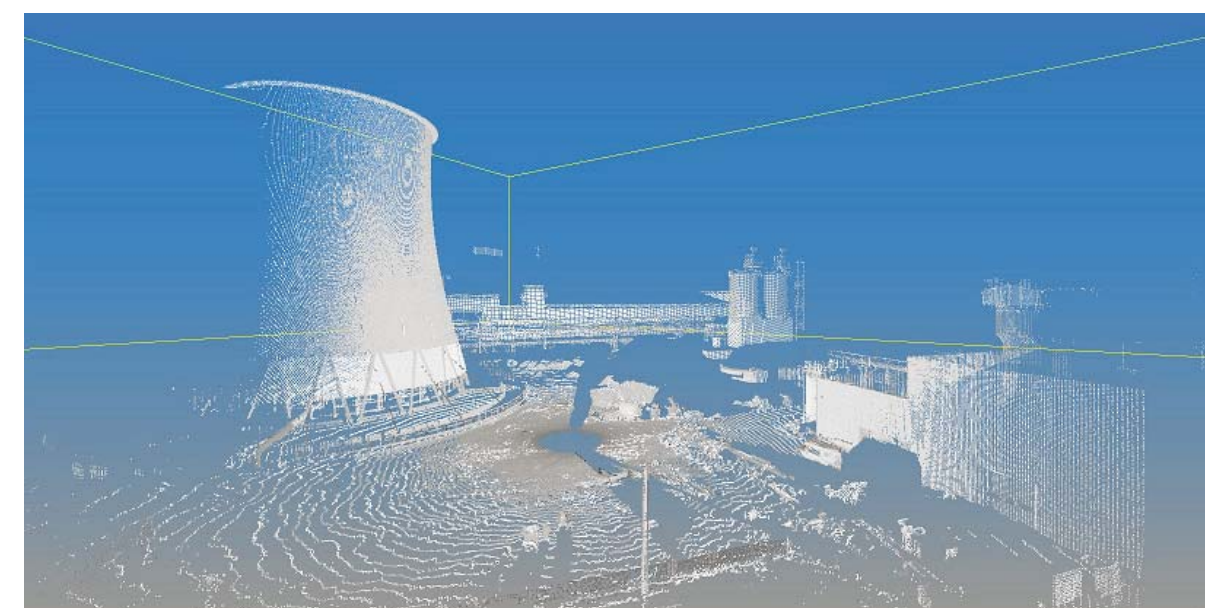

Rys. 5. Widok chmury punktów $\mathrm{z}$ jednego ze stanowisk pomiarowych (opracowanie własne)

Fig. 5. Point cloud view from one of the measuring stations (own elaboration)

Wykonane podczas realizacji niniejszego testu pomiary obejmowały swoim zakresem łącznie sześć skanów wykonanych przy najwyższej rozdzielczości skanera, z zachowaniem kąta horyzontalnego $360^{\circ}$, a także dla każdego stanowiska po jednym skanie szczegółowym obejmującym obiekt chłodni. Wykonano także przynajmniej po pięć skanów szczegółowych obejmujących tarcze referencyjne. Łącznie zarejestrowano około 3,1 GB danych zawierających w sobie po około 3,95 mln punktów o współrzędnych 3D dla każdego skanu budynku chłodni oraz 45 skanów szczegółowych tarcz referencyjnych (każdy skan składał się z ok. 500 tys. punktów). Połączone skany utworzyły jeden wspólny model budynku chłodni kominowej, który sumarycznie liczył ponad $62 \mathrm{mln}$ punktów - na nim to przeprowadzano prace analityczne i weryfikacyjne (rys. 6).

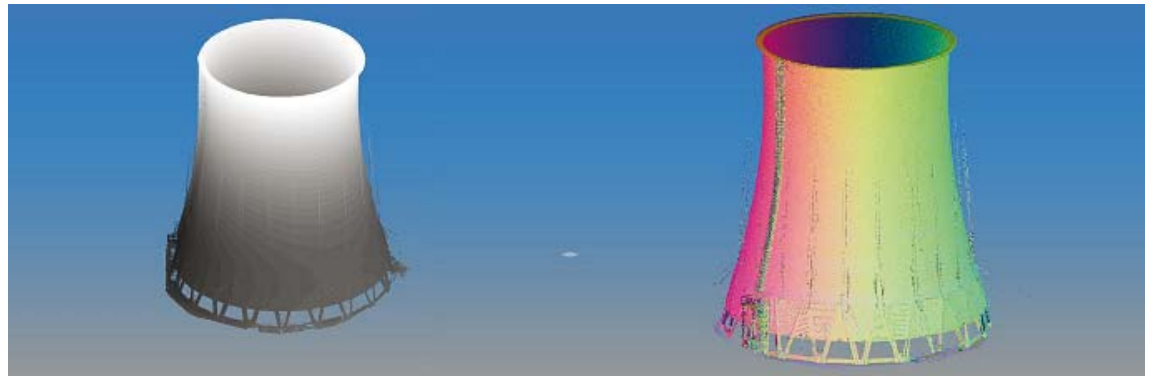

Rys. 6. Widok połączonych skanów obiektu chłodni kominowej w dwóch wersjach wizualizacji kolorystycznej: reflectance oraz inclination (opracowanie własne)

Fig. 6. View of matched laser scans of the cooling tower in two-color visualization versions: reflectance and inclination (own elaboration)

Nawiązanie zarejestrowanych chmur punktów do wspólnego układu georeferencyjnego - w tym przypadku układu obowiązującego dla zakładu przemysłowego - zostało precyzyjnie zaplanowane już na etapie analizy wykonalności projektu. Specjalnie przygotowane do tego celu tarcze szachownicowe zamocowano do wstępnie oczyszczonych powierzchni trwałych konstrukcji stalowych przy zachowaniu ich optymalnej widoczności. Równomierne rozłożenie znaków sygnalizowanych na obiekcie i na sąsiadującym otoczeniu pozwoliło 
na zminimalizowanie propagacji błędu orientacji skanów, jak również wynikłego z tego możliwego skręcenia układu. Pozyskane informacje przetworzono, a następnie poddano dodatkowej analizie mającej na celu zweryfikowanie ich użyteczności zarówno dla celów opracowania na ich podstawie operatu inwentaryzacyjnego, jak i dokumentacji w technologii BIM. Na podstawie zebranego materiału przygotowano zestaw przekrojów, widoków 3D.

Po przeanalizowaniu przygotowanej oraz zgromadzonej dokumentacji powykonawczej uznano, iż stanowi ona cenny materiał wyjściowy zarówno dla opracowania pełnego modelu BIM całego obiektu chłodni kominowej (rys. 7), jak i do opracowania operatu inwentaryzacyjnego z wykonanych pomiarów geometrii obiektu.

Rys. 7. Rzut płaszczyzny poziomu „0” wpasowanej w obiekt dla potrzeb generowania przekrojów (opracowanie własne)

Fig. 7. View of the level ,0" cross section matched into the object for the needs of generating cross sections (own elaboration)

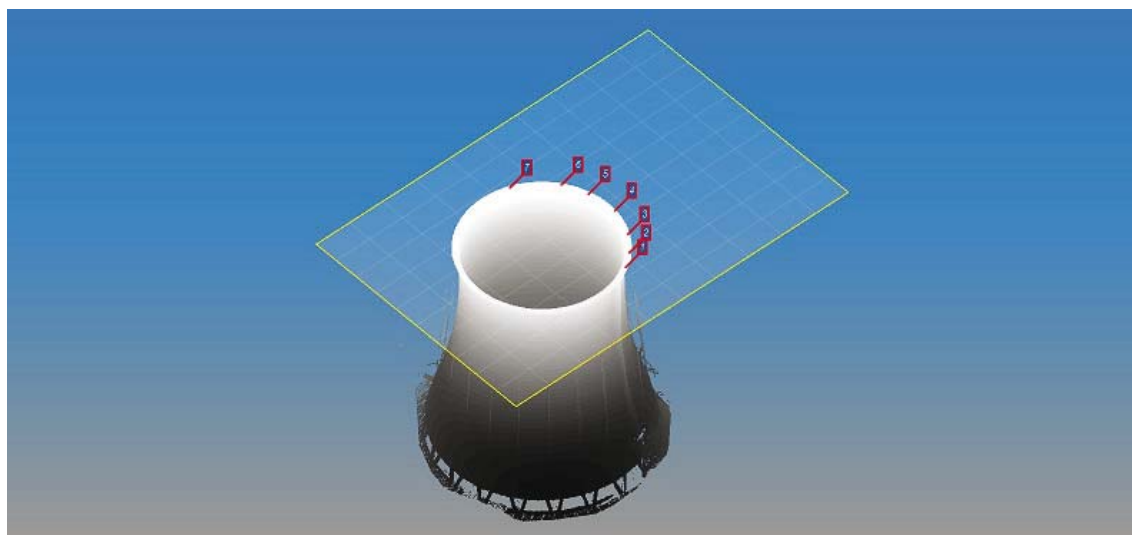

\section{MOŻLIWOŚCI ZASTOSOWANIA ANALIZOWANEGO ROZWIĄZANIA TECHNOLOGICZNEGO}

Po przeprowadzeniu analiz otrzymanych materiałów dokumentacyjnych oraz całej procedury przeprowadzonego pomiaru zasadne staje się wykorzystywanie technologii naziemnego skaningu laserowego TLS w pracach inwentaryzacyjnych w obiektach podobnych do badanej chłodni kominowej. Nieodłącznym elementem tego rodzaju działań nadal jest klasyczny pomiar geodezyjny zapewniający odpowiednią dokładność wpasowania zarejestrowanych chmur punktów w układ georeferencyjny powiązany z układem odniesienia danego zakładu przemysłowego. Jedynie kombinacja tych dwóch rozwiązań technologicznych pozwala na zachowanie odpowiedniej precyzji dowiązania zarejestrowanych skanów do zadanego układu współrzędnych. W tym aspekcie obie technologie pomiarowe stają się jak najbardziej komplementarne, a ich integracja zapewnia poprawność wykonania zadania pomiarowego oraz umożliwia dodatkową kontrolę.

Dzięki mnogości dostarczanych informacji, wykorzystanie technologii fotogrametrycznej staje się rozwiązaniem wręcz nieocenionym pod względem tzw. wartości dodanej. Prawidłowo dobrana technologia skanowania pozwala na wykonanie szybkiej, bezinwazyjnej oraz precyzyjnej inwentaryzacji geometrii obiektu budowlanego - w omawianym przypadku - chłodni kominowej. Brak konieczności instalacji dodatkowych reflektorów czy zapewnienia geodecie dostępu do wszystkich wymaganych miejsc, jak również stosunkowo krótki czas prowadzenia prac pomiarowych w pełni uzasadniają wykorzystanie tej technologii do celów dokumentacyjnych. Precyzyjnie zbudowany model 3D obiektu umożliwia prowadzenie dogłębnych analiz w warunkach kameralnych, bez konieczności dodatkowych wizyt w obiekcie (rys. 8, 9).

Możliwości generowania zestawu przekrojów poprzecznych i podłużnych, analiz poszczególnych płaszczyzn tnących cały obiekt w dowolnym miejscu oraz na dowolnym poziomie czy też analizy porównawcze kolejnych modeli zarejestrowanych w różnych epokach pomiarowych stanowią jedynie kilka podstawowych 


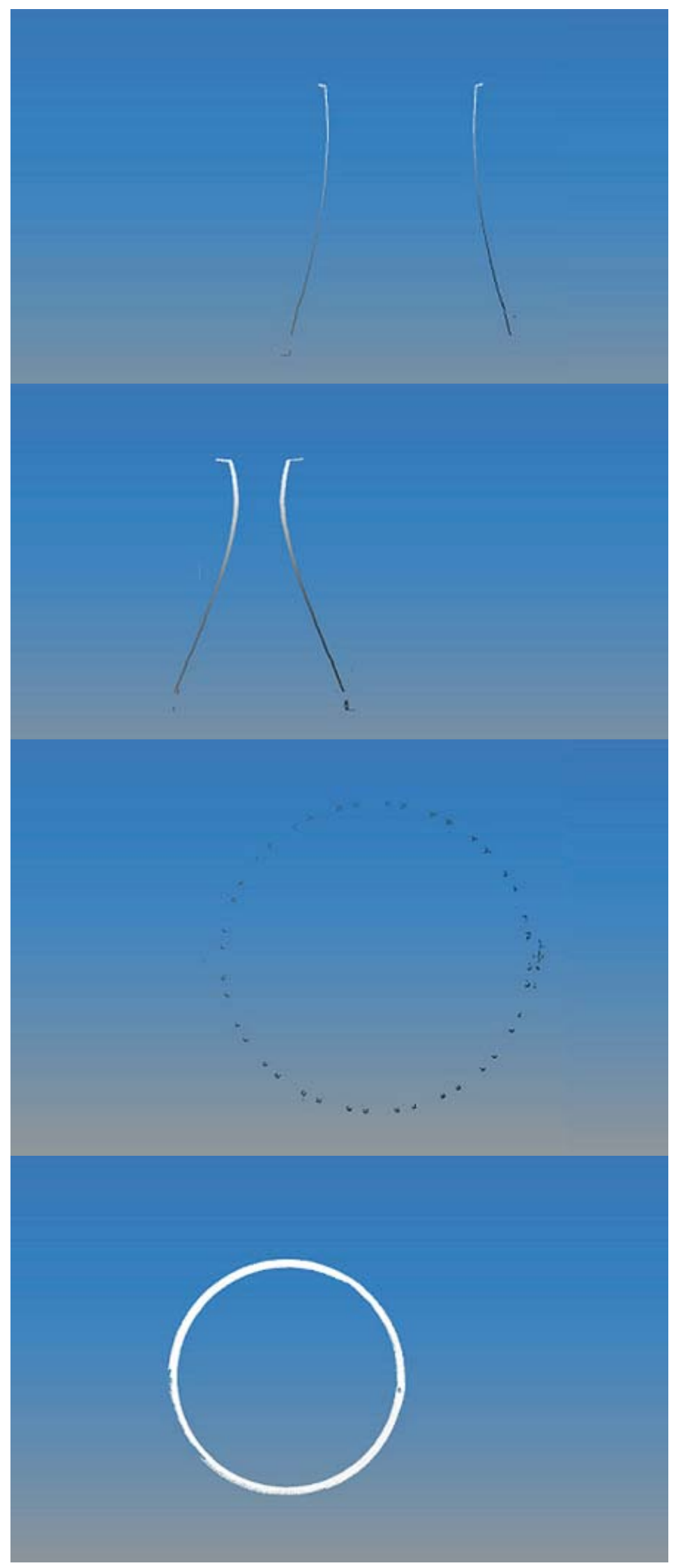

Rys. 8. Przekroje poprzeczne oraz poziome przez konstrukcję chłodni (opracowanie własne)

Fig. 8. Horizontal and vertical cross sections through the cooling tower structure (own elaboration) 


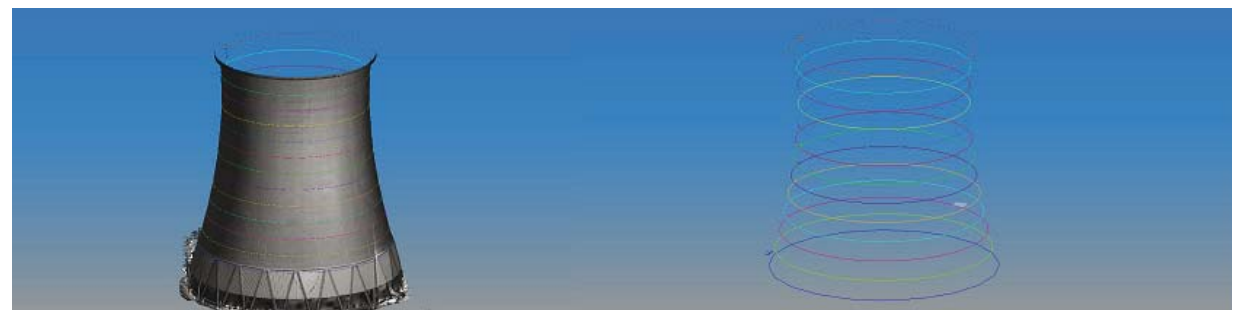

Rys. 9. Widok powierzchniowego modelu chłodni wraz z wygenerowanymi przekrojami poziomymi (opracowanie własne)

Fig. 9. View of the surface model of the cooling tower with its corresponding horizontal cross sections (own elaboration)

funkcjonalności, które możemy zrealizować dla przedmiotowego zagadnienia na bazie danych pochodzących ze skaningu laserowego. Taki stan rzeczy uzasadnia tezę, iż wykorzystanie technologii fotogrametrycznych dla potrzeb pomiaru oraz analiz geometrii obiektu przemysłowego znajduje racjonalne uzasadnienie.

\section{ASPEKT UTRZYMANIA OBIEKTU}

W aspekcie utrzymania obiektu z pomocą przychodzi obecnie coraz popularniejsza technologia BIM, która to, zgodnie ze swoimi założeniami, pozwala zarówno na szybką i bezpośrednią wymianę informacji z innymi podmiotami zaangażowanymi w projekt, jak i na utworzenie kompleksowej relacyjnej bazy danych o obiekcie, wypełnionej informacjami odnośnie jego właściwości (Płaszczyk, Jasiński i Salamak, 2016). W omawianym przypadku podstawowymi informacjami będą dane o czystej geometrii obiektu, a w przyszłości mogą to być również dane pochodzące $\mathrm{z}$ monitoringu deformacji lub określające poziom zmian dotyczących własności fizycznych i strukturalnych obiektu.

Poprzez uzupełnienie kompletnego modelu 3D prowadzonego $\mathrm{w}$ technologii BIM warstwą informacyjną - tzw. metadanymi - otrzymujemy złożoną strukturę, która istniejąc $\mathrm{w}$ środowisku edytowalnym umożliwiającym różnym uprawnionym stronom procesu inwestycyjnego wprowadzanie zmian oraz uzupełnień, pozwala na znaczne usprawnienie procesów decyzyjnych $\mathrm{w}$ trakcie prowadzonych działań (Shanbari, Blinn i Issa, 2016). Parametry techniczne materiałów, z których dany element jest skonstruowany, skład chemiczny, wiek lub wszelkie inne podobne informacje pozwalają na natychmiastowe dokonywanie weryfikacji założeń dotyczących danego elementu w kwestii jego eksploatacji, wymiany, naprawy czy też remontu (BIM Plus, 2017).

Dysponując tak kompleksową bazą danych, zintegrowaną zarówno $\mathrm{z}$ rysunkami technicznymi, jak i z całym modelem 3D, z łatwością możemy uzyskać niezbędne informacje, np. do przeprowadzenia renowacji wybranych powierzchni elementów poszycia lub innego elementu konstrukcji - jak przedstawiono choćby na przykładzie budynku Laboratorium Centrum Wodnego Szkoły Głównej Gospodarstwa Wiejskiego w Warszawie (rys. 10).

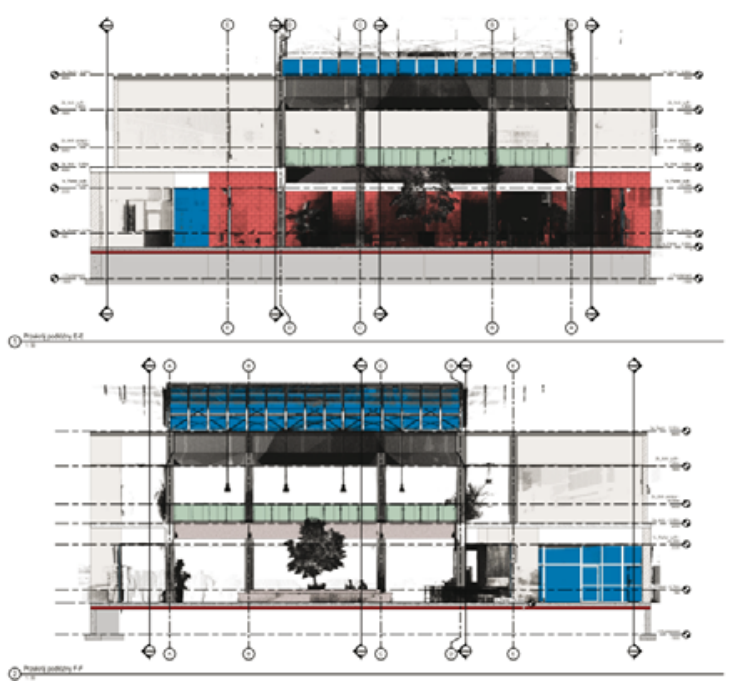

Rys. 10. Przykładowy zestaw przekrojów poprzecznych konstrukcji budynku (Laboratorium Centrum Wodne SGGW)

Fig. 10. Example set of vertical cross sections of a building structure (Laboratory Water Centre of WULS-SGGW) 
Wymiana informacji między zainteresowanymi stronami w kwestii wszelkiego rodzaju aspektów administracji bądź eksploatacji obiektu staje się o wiele bardziej uproszczona, a możliwość automatycznego generowania raportów, widoków i schematów znacznie usprawnia proces decyzyjny, oszczędzając tym samym środki niezbędne na przeprowadzenie danej procedury (Gleason, 2013).

\section{WNIOSKI}

Przeprowadzone prace pomiarowe oraz analizy potwierdzają przyjęte założenie odnośnie celowości wykorzystania technologii naziemnego skaningu laserowego TLS w tworzeniu dokumentacji inwentaryzacyjnej obiektu przemysłowego z punktu widzenia dokładnościowego oraz kompleksowego podejścia do pozyskania dużej ilości informacji w krótkim czasie. Dokumentacja ta poprzez swoją kompletność stanowi optymalną podstawę do dalszego opracowania modelu obiektu w technologii BIM. Istotne wszakże pozostaje zachowanie prawidłowej metodyki akwizycji danych przy uwzględnieniu zasad poprawnego wykonania pomiaru oraz jego późniejszej analizy. Wspomniane elementy będą stanowić kluczowy aspekt w kwestii budowy dalszego modelu 3D ze względu na szczegółowość danych, ich jakość oraz przede wszystkim dokładność - rzutującą na precyzję opracowania końcowego (rys. 11).

Wykorzystanie tak powstałej dokumentacji otwiera szerokie możliwości zarówno w kwestii optymalnego administrowania istniejącym obiektem, odtwarzania utraconej bądź niedostępnej dokumentacji (tzw. inżynieria odwrotna), jak i usprawnia jego dalszą eksploatację. Wzbogacenie informacji geometrycznych pochodzących z pomiaru obiektu o tkankę informacyjną niosącą ze sobą metadane na temat materiału, z którego zostały one wykonane, ich parametrów, właściwości fizycznych oraz wieku pozwalają na natychmiastową weryfikację założeń prac remontowych.

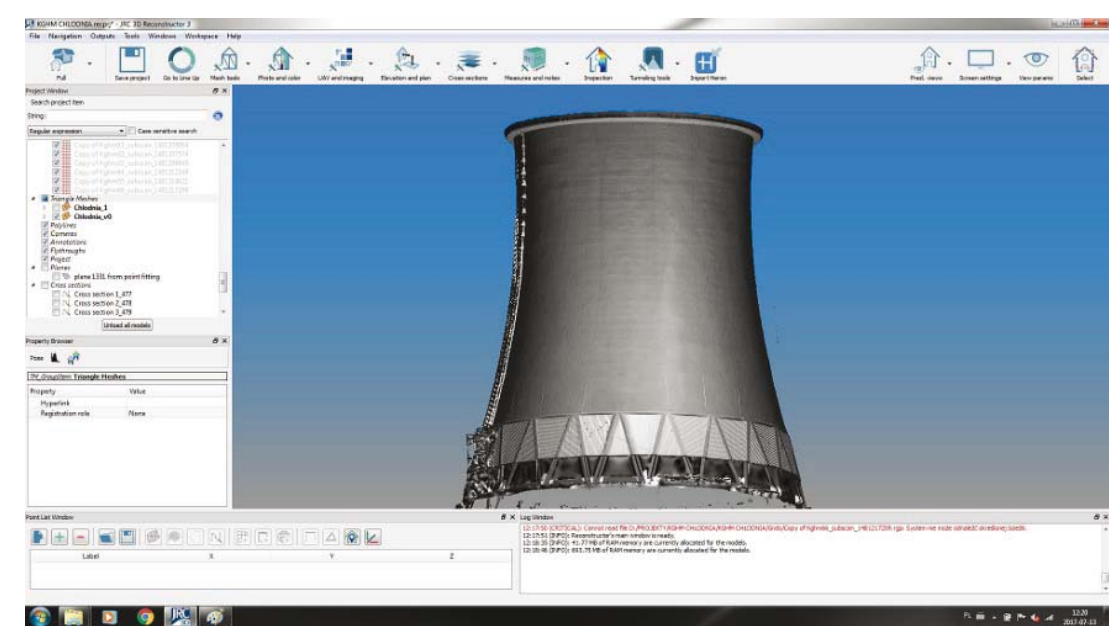

Rys. 11. Widok płaszczyznowy modelu 3D budynku chłodni kominowej (opracowanie własne)

Fig. 11. Three-dimensional model surface view of the cooling tower building (own elaboration)

Wartością dodaną tak przygotowanego modelu jest możliwość prowadzenia regularnych pomiarów inwentaryzacyjnych niezbędnych do zachowania ciągłości produkcyjnej ruchu w zakładzie przemysłowym. Bardzo istotną kwestią jest tutaj integracja rozwiązań fotogrametrycznych - takich jak naziemny skaning laserowy 
- z metodami klasycznej geodezji, które zapewniają najwyższy poziom dokładności opracowywanej dokumentacji. Różnorodność zastosowań tak zintegrowanego podejścia pozwala na jego rekomendację podczas prowadzenia rutynowych prac inwentaryzacyjnych obiektów przemysłowych, jak również projektowania i wdrażania systemów monitoringu stanu konstrukcji (SHM).

\section{Podziękowania}

Autorzy dziękują firmie Czerski Trade Polska Sp. z o.o. za udostępnienie skanera laserowego oraz niezbędnego oprogramowania na potrzeby niniejszego artykułu.

\section{PIŚMIENNICTWO}

BIM Plus. (2017). Pobrano z lokalizacji: http://www.bimplus.co.uk/technology/laser-scanning,BIM Blog, http://www. bimblog.pl/2016/08/teoria-ewolucji-bim-3d-7d/\#more-3854.

Gleason, D. (2013). Laser Scanning for an Integrated BIM. Pobrano z lokalizacji: https://www.tekla.com/de/trimble$5 \mathrm{~d}$ /laser-scanning-for-bim.pdf.

Głowacki, T., Grzempowski, P., Sudoł, E., Wajs, J. i Zając, M., (2016). The assessment of the application of terrestrial laser scanning for measuring the geometrics of cooling towers. Geomatics, Landmanagement and Landscape, 4, 49-57.

Gocał, J. (1999). Geodezja inżynieryjno-przemysłowa, część 1. Kraków: Uczelniane Wydawnictwa Naukowo-Dydaktyczne AGH.

Hardin, B. i McCool, D. (2015). BIM and Construction Management-proven tools, methods and workflows. Indianapolis: John Wiley \& Sons.

Karsznia, K. (2014). Współczesna technologia skanowania laserowego 3D w monitorowaniu przemieszczeń i deformacji obiektów mostowych. Mosty, 1, 24-27.

Leica TPS800 Series. (2006). Instrukcja obstugi, wersja 4.0. Leica Geosystems AG. Heerbrugg.

Pawłowski, W. (2015). Uwarunkowania prawne i techniczne procedur geodezyjnych w budownictwie. Monografie Politechniki Łódzkiej.

Płaszczyk, T., Jasiński, M. i Salamak, M. (2016). Modelowanie geometrii wybranych elementów konstrukcji podpór obiektów mostowych w technologii BIM. Mosty, 5, 22-27.

Shanbari, H. A., Blinn, N. M. i Issa, R. R. (2016). Laser scanning technology and BIM in construction management education. Pobrano z lokalizacji: http://www.itcon.org/papers/2016_14.content.09623.pdf.

Stonex X300. Pobrano z lokalizacji: http://www.stonexpositioning.com/index.php/en/products/laser-scanners/x300-detail.

Szulborski, K. (1999). Wytyczne konstrukcyjne i realizacyjne geodezyjnego monitoringu przemieszczeń obejmujące obiekty nowo wznoszone z wielopoziomowymi garażami podziemnymi oraz zabudowę miejską. W W. Prószyński (red.), Geodezyjny monitoring przemieszczeń podczas wznoszenia obiektów w głębokich wykopach - Aspekty naukowo-techniczne i organizacyjne.(strony 20-34). Warszawa: Politechnika Warszawska.

Tomana, A. (2016). BIM - Innowacyjna technologia w budownictwie - podstawy, standardy, narzędzia. Kraków.

Uchański, J., Falkowski, P. i Uchański, Ł. (2010). Tradycja i nowoczesność w inwentaryzacji obiektów architektonicznych ze szczególnym uwzględnieniem obiektów zabytkowych. W J.P. Piotrowski i in. (red.), Labor Omnia Vincit Almamer (strony 137-167). Warszawa: Druktur.

Uchański, Ł. i Soerensen L. (2010). Technologia naziemnego skaningu laserowego w zagadnieniach inżynierii odwrotnej oraz analiz procesów dynamicznych. Archiwum Fotogrametrii i Teledetekcji, 21, 415-424.

Zaczek-Peplinska, J. i Popielski, P. (2013). Technologia naziemnego skaningu laserowego jako narzędzie do weryfikacji numerycznych modeli zachowania obiektów hydrotechnicznych. W J. Winter, A. Kosik, A. Wit (red.), Zapory - bezpieczeństwo i kierunki rozwoju (strony 218-229). Warszawa: Instytut Meteorologii i Gospodarki Wodnej, Państwowy Instytut Wydawniczy. 


\title{
INVENTORY SURVEYING OF INDUSTRIAL OBJECTS USING TERRESTRIAL LASER SCANNING IN THE ASPECT OF IMPLEMENTING BIM TECHNOLOGY
}

\begin{abstract}
Geodetic inventory surveying is an essential element of the maintenance in industrial plants. It concerns, for example, a cooling tower, for which the authors have assessed the use of terrestrial laser scanning (TLS) in the aspect of providing inventory measurements. The primary research motivation was the question whether it was possible to verify the use of the laser scanning technology as a supplement or even as a substitute for classical land surveying methods. Another important aspect was the problem of data acquisition necessary to validate the usability of a BIM model (building information modeling) through restoring its structural shape aided by the design information existing in an interactive 3D environment. The BIM technology allows for conducting both extensive structural and strength analysis, providing efficient facility management as well as for optimal planning of potential repairs.
\end{abstract}

Key words: terrestrial laser scanning (TLS), BIM, inventory works, cooling tower, point cloud, 3D model 